\section{REACTIVE POWER ANALYSIS AT SOLAR POWER PLANT}

\author{
Aida Fazliana Abdul Kadira, Hanisah Mupangata, Dalila \\ Mat Saidb, Zulhani Rasina
}

aFaculty of Electrical Engineering, Universiti Teknikal Malaysia Melaka, UTEM, Jalan Hang Tuah Jaya, 76100 Durian Tunggal, Melaka, Malaysia

bCentre of Electrical Energy Systems (CEES), School of Electrical Engineering, Universiti Teknologi Malaysia, 81310 UTM Johor Bahru, Johor, Malaysia
Article history

Received

3 August 2020

Received in revised form

3 January 2021

Accepted

12 January 2021

Published online

23 February 2021

*Corresponding author fazliana@.utem.edu.my

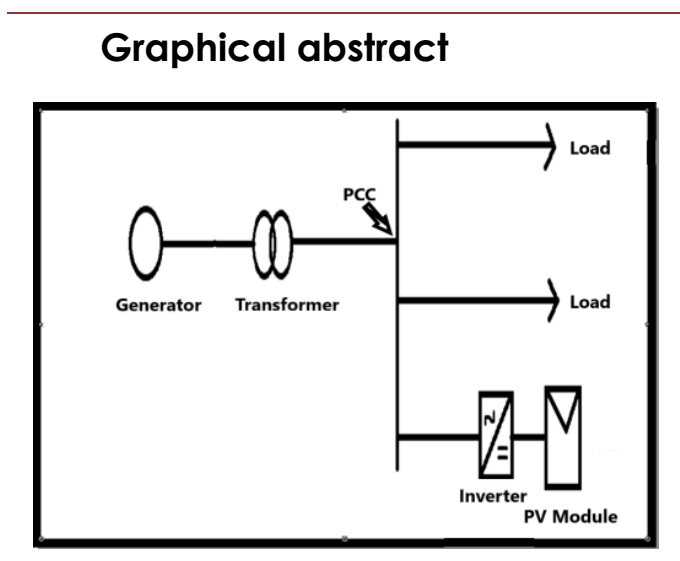

As the more extensive scale of photovoltaic power plants is being installed, the electrical system can face some challenges related to reactive power control and voltage support. Thus, many countries have updated their grid codes to permit a smooth interaction between these power plants with the transmission system. Therefore, the Inverter of Photovoltaic (PV) Solar connected to grid system are required to supply rated power output (MW) at Point of Common Coupling (PCC) between the limits of 0.85 power factor lagging, and 0.95 leading follow the Malaysian Grid Code (MGC) requirement.

\begin{abstract}
Reactive power is essential to control the power system's voltage stability as the reactive power is directly proportional to the voltage. Hence, every new solar photovoltaic (PV) plant installed in the grid system must comply with the grid code requirements to ensure that the electricity supply remains stable and reliable. As the more penetration of PV plants, the electrical system will face some challenges related to reactive power control and voltage support. Thus, many countries including Malaysia have updated their grid codes to permit a smooth interaction between these new plants with the grid system. The inverter of PV solar connected to grid system are required to supply rated power output (MW) at point of common coupling (PCC) between the limits of 0.85 power factor lagging, and 0.95 leading follow to the Malaysian Grid Code (MGC) requirement. Hence, this research aims to design a controller for the PV inverter in Matlab/Simulink that able to absorb and supply the reactive power. Then, the comparison will execute between the simulation results and the MGC requirement. However, due to power loss in the system, the $\mathrm{PV}$ inverter controller may not comply with the reactive power capability as the MGC requirement. Thus, the PV system need to integrate with the capacitor bank as a reactive power compensator.
\end{abstract}

Keywords: Reactive power capability, Solar PV plant, grid connected Solar PV, Inverter controller, Malaysian Grid Code

\begin{abstract}
Abstrak
Kuasa reaktif adalah penting untuk mengawal kestabilan voltan dalam sistem kuasa kerana kuasa reaktif adalah berkadar terus dengan voltan. Jadi, setiap loji kuasa solar fotovolta (FV) baru yang dipasang mesti mematuhi keperluan kod grid untuk memastikan bekalan elektrik stabil dan boleh dipercayai. Semakin banyak penembusan loji FV, sistem elektrik akan menghadapi beberapa cabaran yang berkaitan dengan kawalan kuasa reaktif dan sokongan voltan. Oleh itu, banyak negara termasuk Malaysia telah mengemaskini kod grid mereka untuk
\end{abstract}


membolehkan interaksi yang lancar antara loji baru ini dengan sistem grid. Penyongsang untuk sistem FV solar yang disambungkan ke sistem grid perlu membekalkan keluaran kuasa (MW) pada titik penyambungan bersama (TPB) di antara faktor kuasa 0.85 mengekor, dan 0.95 mendulu mengikut keperluan kod grid Malaysia (KGM). Oleh itu, kajian ini bertujuan untuk merekabentuk pengawalan penyongsang FV di Matlab / Simulink yang mampu menyerap dan membekalkan kuasa reaktif. Kemudian, perbandingan akan dilakukan di antara hasil simulasi dengan keperluan kod grid Malaysia. Walaubagaimanapun, disebabkan kehilangan kuasa dalam sistem, pengawalan penyongsang FV mungkin tidak dapat mematuhi keupayaan kuasa reaktif sebagaimana yang diperlukan oleh KGM. Oleh itu, system FV perlu digandingkan dengan bank kapasitor sebagai pemampas kuasa reaktif.

Kata kunci: Keupayaan kuasa reaktif, Loji Solar FotoVolta (FV), Grid disambungkan ke Solar FV, kawalan penyongsang, kod grid Malaysia

(C) 2021 Penerbit UTM Press. All rights reserved

\subsection{INTRODUCTION}

Dependence on fossil fuel as our primary source of electricity is becoming a threat to the global climate system's stability as it will increase carbon dioxide emissions[1]. We need to use independent and environmentally clean energy, such as renewable energy, to overcome this problem. Renewable energy is the energy produced by natural processes that are continuously replenished, such as sunlight and wind. This energy cannot be exhausted, renewed continually, and did not emit greenhouse gases into the air [2]. In this study, we will focus on PV Solar connected to the grid system. The illustration of a PV solar connected to the grid system is shown in Figure 1. To supply electricity from PV solar to the load, the DC power needs to be converted into AC power using inverter because most of the loads require $A C$ power to operates. AC loads cause the current and voltage are not in phase caused by the existence of inductive and capacitive in AC loads. When current and voltage are not in phase, it will produce a real and imaginary component, which is active power and reactive power. As the broader scale of photovoltaic power plants is being installed, the electrical system can face some challenges related to reactive power control and voltage support. Malaysian Grid Code (MGC) as shown in Figure 2 has set the reactive power requirement for the system to be followed to maintain a smooth interaction and voltage stability of the system. Hence, a PV inverter must be controlled to have the ability to supply or absorb reactive power, but due to power loss, the inverter may not fulfil the MCG requirement [3]. Hence a reactive power compensation may be needed to able the system to meet the MGC requirement [3].

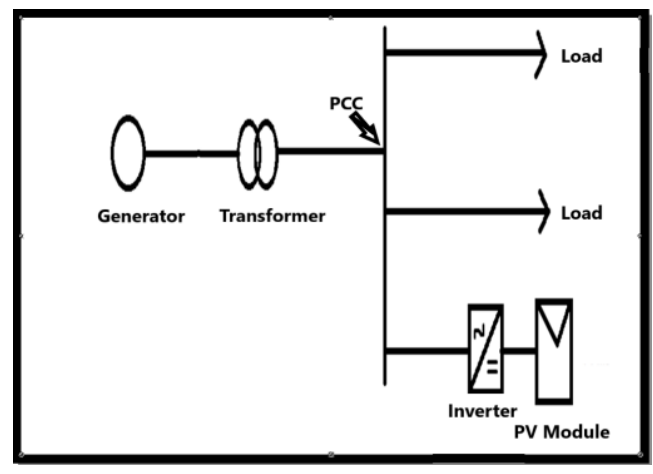

Figure 1 Solar PV Connected to Grid

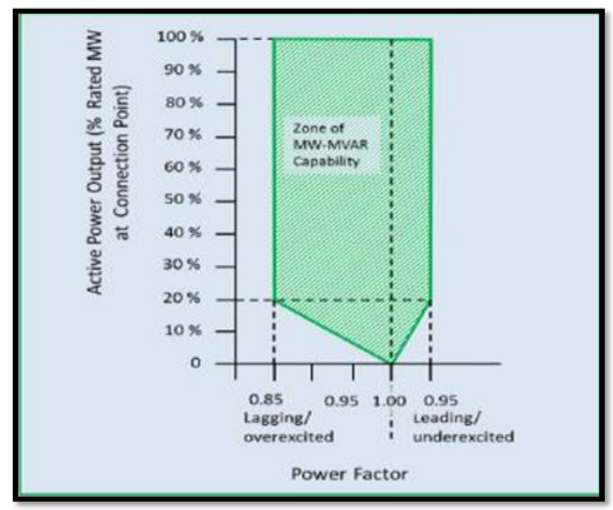

Figure 2 MGC requirement 


\subsection{METHODOLOGY}

\subsection{Maximum Power Point Tracking}

In this study, the Perturb and Observe (P\&O) method is used to implement the MPPT, and the algorithm is based on the calculation of the PV array current and voltage. P\&O method is used to modify the operating voltage of the PV panel using a voltage sensor until the maximum power is obtained. The P\&O technique is demonstrated in Figure 3. Given a voltage perturbation first, then $V(k)$ and $I(k)$ are sampled at time $k$, and then calculate power $P(k)=V(k) \times I(k)$. Compare $P(k)$ with $P(k-1)$; if power increases keep searching in the same direction, while if power decreases, search in the opposite direction to get final output voltage, $\mathrm{V}$.

\subsection{Reactive Power Control Q(V)}

Based on [9], when a $Q-V$ droop is used, the inverter measures the terminal voltage and compares this to the reference value. The reactive power is adjusted by altering the reactive component of the inverter current. This reactive power adjustment is expressed in Eq. (2.1).

$$
Q=Q_{0}-n q\left(V_{0}-V\right)
$$

Where Qo is the reactive power delivered/consumed by the inverter at setpoint voltage, Vo and nq is the gradient of the droop, which determines how much the reactive power $Q$ will change in response to a change in voltage $V$. $Q(V)$ Droop control characteristic can be illustrated as shown in Figure 4. As the voltage increase, the controller will be supplying $Q$ (leading) and if the voltage decrease, the controller will absorb $Q$ (lagging).

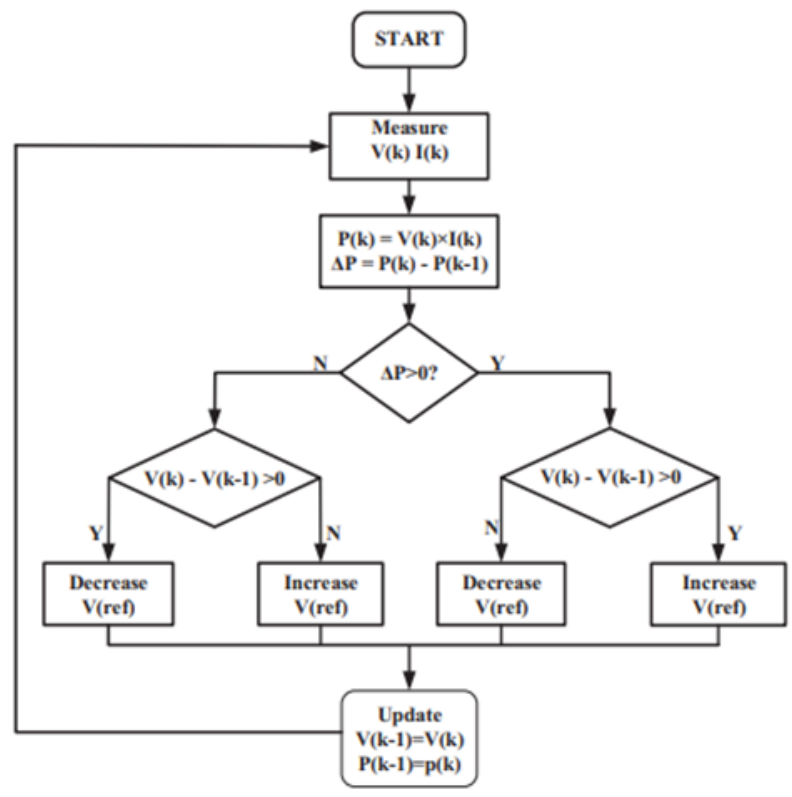

Figure 3 Flowchart of MPPT control

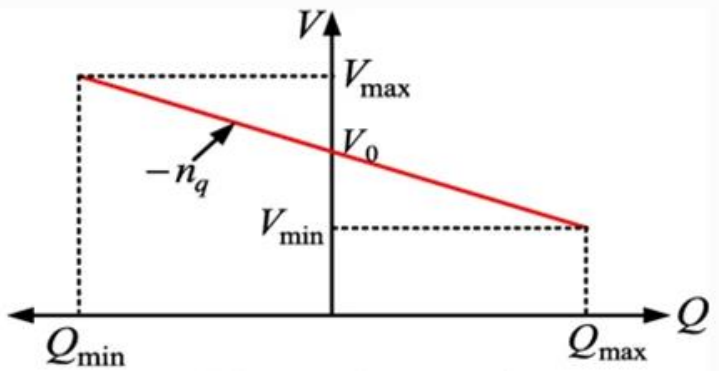

Figure 4 Characteristics of $Q(V)$ Droop Control

\subsection{Active Power Control P(F)}

The inverter will adjust its power accordingly by comparing the measured frequency to a reference (nominal grid frequency) value consequently, active power adjustment is expressed as shown in Eq. (2.2) where PO is the power delivered by the inverter at setpoint frequency fo and $\mathrm{kf}$ is the gradient of the droop, which determines how much the active power $P$ will change in response to a change in frequency $f[9]$.

$$
P(f)=P O-(f o-f) k f
$$

Figure 5 shows the characteristic of $\mathrm{P}(\mathrm{f})$ control, as the active power increase the frequency decrease.

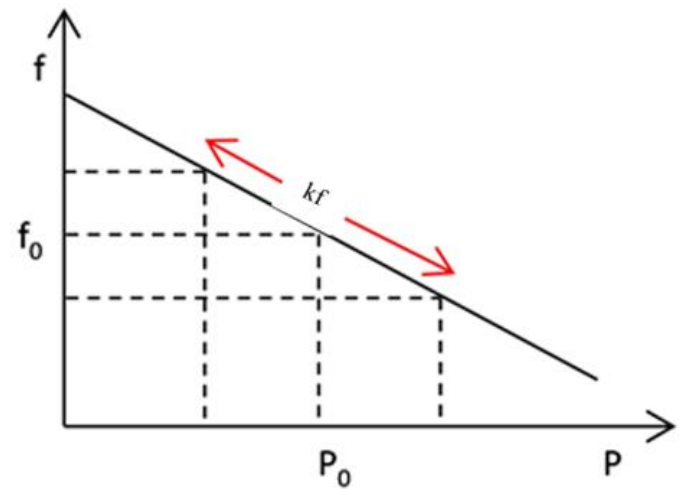

Figure 5 Characteristic of $\mathrm{P}(\mathrm{f})$ Droop Control

\subsection{Voltage and Current Control}

Voltage and current controllers are designed to reject high-frequency disturbance and provide adequate damping for the output filter [11].

\subsection{Phase Lock Loop Control (PLL)}

According to [12], PLL is used to match the frequency of the inverter with the grid and lock on to that frequency $(50 \mathrm{~Hz})$. The basic construction of PLL control is shown in Figure 6. The reference signal of the sine wave is a system frequency of the utility grid, and the other input of the feedback system is the inverter output frequency. The two input will be fed into the block phase detector to compare both input and 
generate an error. The error will compute how much the frequency of the two input is out of phase. If they are in phase (same frequency), there will be zero error. Then the error fed into the Low Pass Filter (LP Filter) to filters out the high frequency that generated in the phase detector. The voltage-controlled oscillator is to convert DC input from the LP Filter into an equivalent AC output. If the dc input of the voltage source oscillator is $0 \mathrm{v}$ which mean 0 error, it will generate $50 \mathrm{~Hz}$ sinusoidal waveform output. If the input if positive DC, it will generate higher than $50 \mathrm{~Hz}$ output of the AC waveform and if the input is negative DC, it will generate less than $50 \mathrm{~Hz}$ output of the AC waveform.

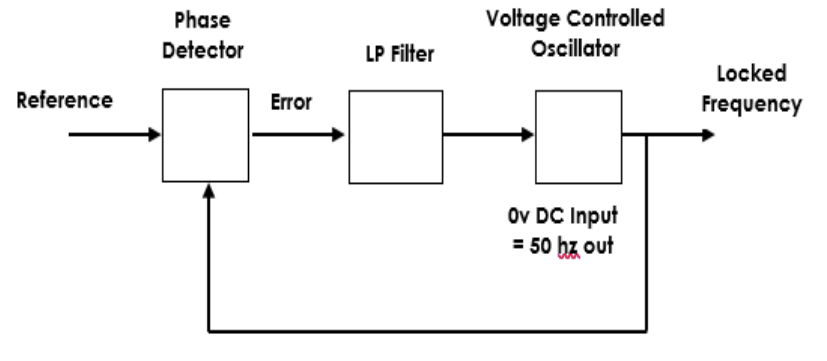

Input of the Feedback System

Figure 6 Basic construction of PLL control

\subsection{Pulse Width Modulator (PWM)}

Based on [12] Pulse Width Modulation or PWM technology is used in inverters to give a steady output voltage irrespective of the load. The Inverters based on the PWM technology are more superior to conventional inverters. The use of MOSFETs in the output stage and the PWM technology makes these inverters ideal for all types of loads. In addition to the pulse width modulation, the PWM Inverters have additional circuits for protection and voltage control.

\subsection{Park's Transformation}

According to the article [10], Park's transformation is used to transform three phase $A C$ quantities $(A B C)$ into two DC quantities (dq0). The 0-component is zero for the balanced systems. The DC quantities facilitate easier filtering and easy to control the three-phase system. Active and reactive power can be controlled independently by controlling the dq components. The three-phase output voltage and current, $x$ in the abc frame of the inverter can be represented, as shown in Eq. (2.3) [10].

$$
\left[\begin{array}{l}
x_{a} \\
x_{b} \\
x_{c}
\end{array}\right]=\left[\begin{array}{c}
x_{m} \cos (\omega t) \\
x_{m} \cos \left(\omega t-\frac{2 \pi}{3}\right) \\
x_{m} \cos \left(\omega t+\frac{2 \pi}{3}\right)
\end{array}\right]
$$

where $\mathrm{Xm}$ is the maximum magnitude of voltage or current, $\omega$ is the angular frequency. The three-phase stationary coordinate system can be transformed into the dq0 rotating coordinate system by Park's transformation as described as Equation (2.4). The real power and reactive power can be expressed as in Equation (2.5) and (2.6) [10].

$$
\begin{gathered}
T_{a b c \rightarrow d q}=\frac{2}{3}\left[\begin{array}{rrr}
\cos (\omega t) & \cos \left(\omega t-\frac{2 \pi}{3}\right) & \cos \left(\omega t+\frac{2 \pi}{3}\right) \\
\sin (\omega t) & \sin \left(\omega t-\frac{2 \pi}{3}\right) & \sin \left(\omega t+\frac{2 \pi}{3}\right)
\end{array}\right] \\
P=\frac{3}{2}\left[v_{q} i_{q}+v_{d} i_{d}\right] \\
Q=\frac{3}{2}\left[v_{q} i_{d}-v_{d} i_{q}\right]
\end{gathered}
$$

\subsection{Simulation in Matlab/Simulink}

PV Solar connected to the grid system is designed using Matlab/Simulink, as shown in Figure 7. The system consists of a PV Array, DC to DC boost converter, inverter (IGBT diode), RLC filter, loads, circuit breaker, transformer, line impedance and grid. The parameter of the system is shown in Table 1.

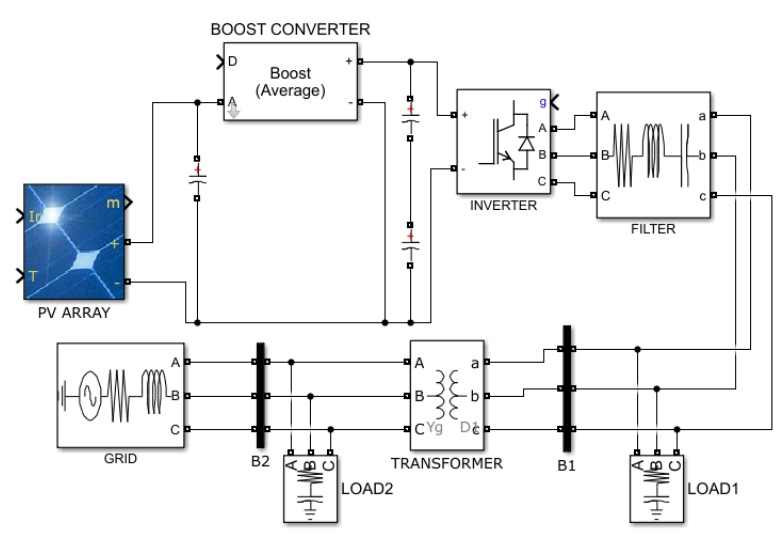

Figure 7 PV Solar connected to grid system 
Table 1 Parameter of the PV Solar connected to grid system

\begin{tabular}{|c|c|}
\hline PARAMETER & VALUE \\
\hline Pv maximum actual power & $100 \mathrm{~kW}$ \\
\hline Load 1 & $15 \mathrm{k}+10 \mathrm{ki}$ \\
\hline Load 2 & $75 \mathrm{k}+20 \mathrm{ki}$ \\
\hline RLC filter & $L=0.4 e-3, R=0.02$, \\
& $\mathrm{C}=2500 \times 10^{-6}$ \\
\hline Capacitor bank & $10 \mathrm{kVAR}$ \\
\hline Line impedence & $0.01+\left(1.27 \times 10^{-4}\right) i$ \\
\hline Transformer & $13.8 \mathrm{kv}: 280 \mathrm{v}$ \\
\end{tabular}

To get the maximum power from the PV panel, MPPT control (P\&O method) is used in the simulation in Matlab/Simulink, as shown in Figure 8.

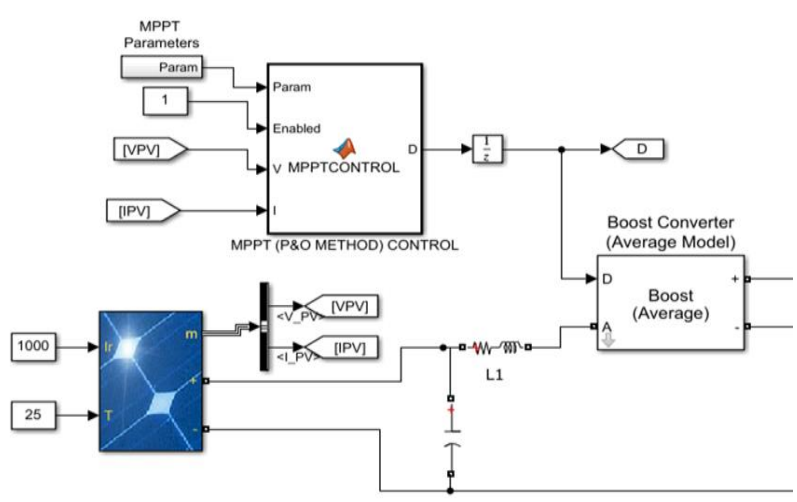

Figure 8 The MPPT (P\&O method) in Matlab/Simulink

\subsection{Inverter Control}

Inverter control consists of a PWM generator, reactive power controller, active power controller, current controller and voltage controller is designed in Matlab/Simulink, as shown in Figure 9. The parameter of the inverter control is shown in Table 2.

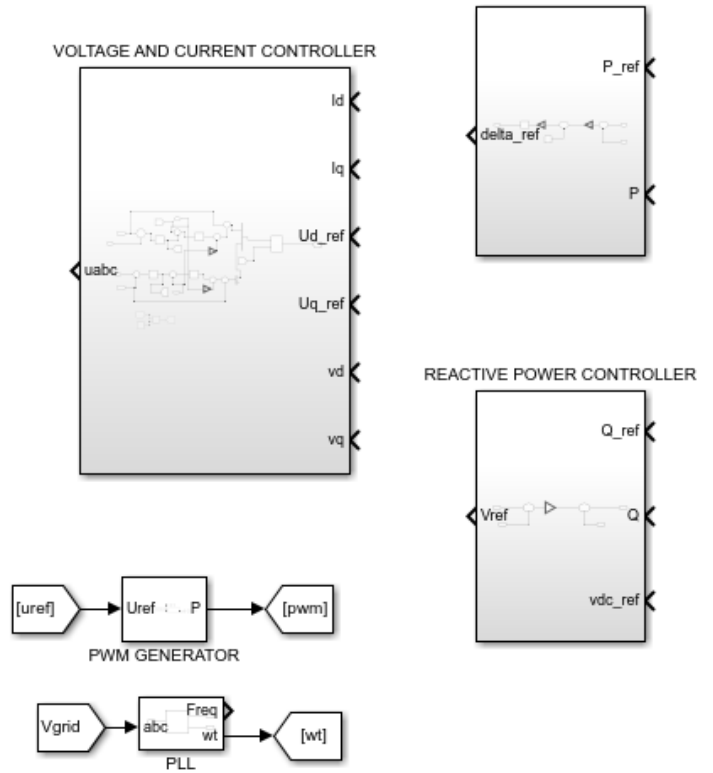

Figure 9 Inverter control in Matlab/Simulink

Table 2 Parameter of Inverter control in Matlab/Simulink

\begin{tabular}{|c|c|}
\hline PARAMETER & VALUE \\
\hline $\mathrm{Kp}$ & $K P 1=0.05, \quad K P 2=0.98$, \\
& $K P 3=0.031, \quad K P 4=0.62$ \\
\hline $\mathrm{Ki}$ & $K I 1=14.2, \quad K I 2=2.46$, \\
& $K I 3=11.8, \quad K I 4=9.26$ \\
\hline Frequency droop & $0.8 \times 10^{-5}$ \\
\hline Voltage droop & $0.3 \times 10^{-5}$ \\
\hline Qref & 0.85 lagging to 0.85 leading \\
\hline
\end{tabular}

\subsection{Reactive Power Compensator (Capacitor Bank)}

The capacitor bank is added to the system in Matlab Simulink, as shown in Figure 10. The value of the capacitor bank is determined by the comparison with previous work which is 10 percent from the maximum actual power.

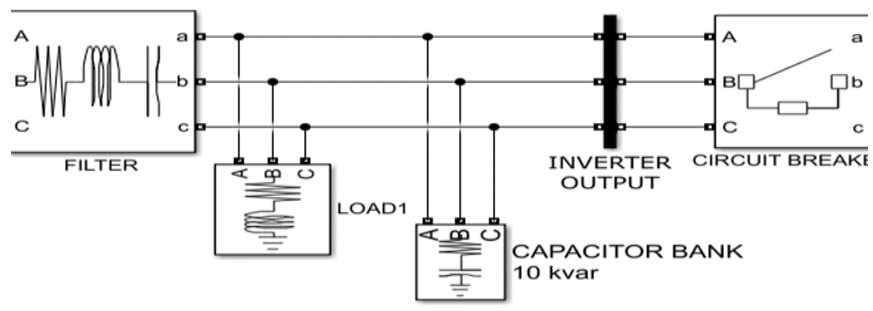

Figure 10 Capacitor bank is added in Matlab Simulink 


\subsection{RESULTS AND DISCUSSION}

\subsection{Malaysian Grid Requirement (MGC)}

Photovoltaic (PV) Solar connected to the grid system should be able to supply rated power output (MW) at any point between the limits of 0.85 power factor lagging and 0.95 power factor leading. For this study, the maximum real power of the solar $\mathrm{PV}$ is $100 \mathrm{KW}$, from the calculation, the inverter must able to provide the reactive power in between 61.96 KVAR lagging to 32.86 KVAR leading. The result of the calculation of $P$ and $Q$ follows the $M G C$ requirement is tabulated in Table 3, and the data is plotted into P VS Q graph, as shown in Figure 11.

Table 3 MGC requirement of 0.85 lagging to 0.95 leading power factor

\begin{tabular}{|l|l|}
\hline $\mathrm{P} / \mathrm{KW}$ & $\mathrm{Q} / \mathrm{KVAR}$ \\
\hline 100 & 61.96 \\
\hline 20 & 61.96 \\
\hline 0 & 0 \\
\hline 20 & -32.86 \\
\hline 100 & -32.86 \\
\hline
\end{tabular}

P VS Q

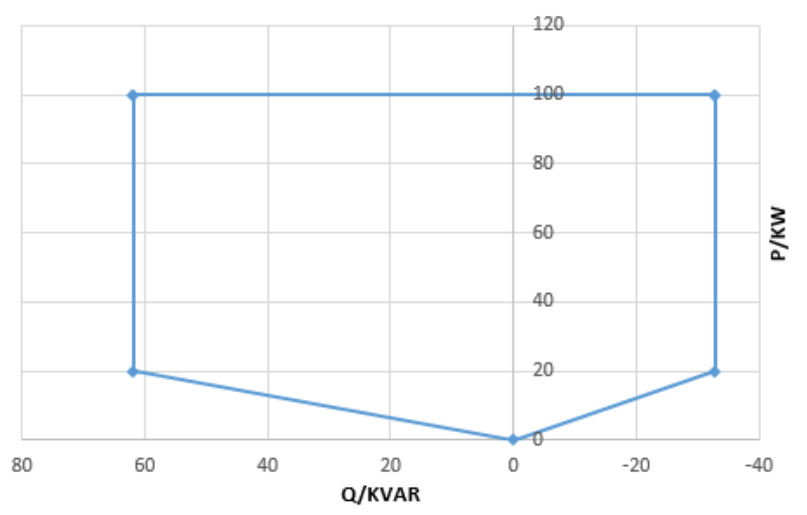

Figure 11 Graph of MGC requirement for maximum power = $100 \mathrm{KW}$

\subsection{Peak Load: P VS Q without Capacitor Bank}

From Table 4, with different penetration of active power, $P$ injected at the inverter, the system can absorb (lagging) and supply (leading) reactive power, $Q$ at PCC. The highest $Q$ it can absorb is 18.73 $\mathrm{kW}$, and most top $\mathrm{Q}$ it can supply is $-13.44 \mathrm{kVAR}$
Table 4 Data of Peak Load without capacitor bank

\begin{tabular}{|c|c|c|c|}
\hline INVERTER (INJECTION) & \multicolumn{3}{|c|}{ PCC (MEASURE) } \\
\hline $\mathrm{P} / \mathrm{KW}$ & $\mathrm{P} / \mathrm{KW}$ & Q/KVAR & V/PU \\
\hline \multicolumn{4}{|c|}{ Lagging/Overexcited } \\
\hline 4.7 & 3.9 & 6 & 0.12 \\
\hline 10.7 & 11.6 & 0.92 & 0.2 \\
\hline 36.3 & 34.2 & 7.3 & 0.44 \\
\hline 92.4 & 92.8 & 16.2 & 0.9 \\
\hline 120 & 120 & 18.73 & 1.05 \\
\hline \multicolumn{4}{|c|}{ Leading/Underexcited } \\
\hline $\mathrm{P} / \mathrm{KW}$ & $\mathrm{P} / \mathrm{KW}$ & Q/KVAR & V/PU \\
\hline 104 & 106 & -13.44 & 1.05 \\
\hline 76.4 & 78.1 & -11.64 & 0.9 \\
\hline 19 & 20 & -5.91 & 0.44 \\
\hline 3.1 & 3.7 & -3.0 & 0.2 \\
\hline 0.3 & 0.08 & -4.1 & 0.12 \\
\hline
\end{tabular}

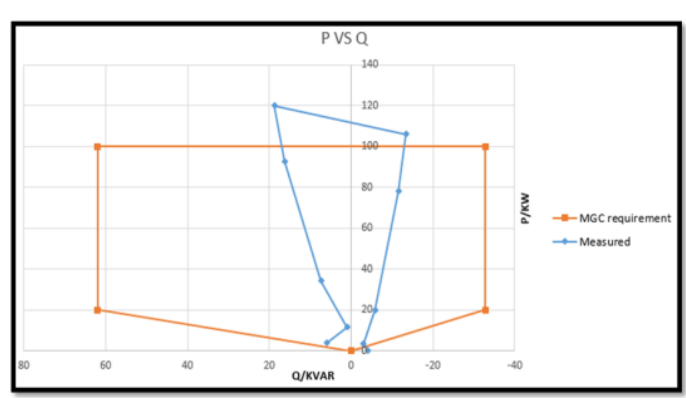

Figure 12 Graph P VS Q for peak load without capacitor bank

From the data in Table 4, graph P VS Q has been plotted in the same graph as the MGC requirement, as shown in Figure 12. As you can see from the figure, the inverter control is capable of supplying and absorbing reactive power but it not adequate to fulfil the Malaysian Grid Code requirement of 0.85 power factor lagging to 0.95 power factor leading.

\subsection{Light load: P VS Q Without Capacitor Bank}

From Table 5, with different penetration of active power, $P$ injected at the inverter, the system is able to absorb (lagging) and supply (leading) reactive power, $Q$ at PCC. The highest $Q$ it can absorb is 8.08 $\mathrm{kW}$, and most top $\mathrm{Q}$ it can supply is $-13.87 \mathrm{kVAR}$ 
Table 5 Data of light load without capacitor bank

\begin{tabular}{|c|c|c|c|}
\hline INVERTER (INJECTION) & \multicolumn{3}{|c|}{ PCC (MEASURE) } \\
\hline $\mathrm{P} / \mathrm{KW}$ & $\mathrm{P} / \mathrm{KW}$ & Q/KVAR & V/PU \\
\hline \multicolumn{4}{|c|}{ Lagging/Overexcited } \\
\hline 0.3 & 0 & 0.2 & 0.2 \\
\hline 4.6 & 4.5 & 2.7 & 0.25 \\
\hline 22.4 & 21.6 & 6.08 & 0.53 \\
\hline 82 & 83.8 & 12.3 & 1.01 \\
\hline 104 & 101 & 8.08 & 1.1 \\
\hline \multicolumn{4}{|c|}{ Leading/Underexcited } \\
\hline $\mathrm{P} / \mathrm{KW}$ & $\mathrm{P} / \mathrm{KW}$ & Q/KVAR & V/PU \\
\hline 109 & 107 & -13.87 & 1.09 \\
\hline 80.08 & 82.46 & -12.35 & 0.95 \\
\hline 20.42 & 21.5 & -6.3 & 0.47 \\
\hline 3.29 & 3.87 & -3.11 & 0.3 \\
\hline 0.27 & 0.12 & -4.07 & 0.12 \\
\hline
\end{tabular}

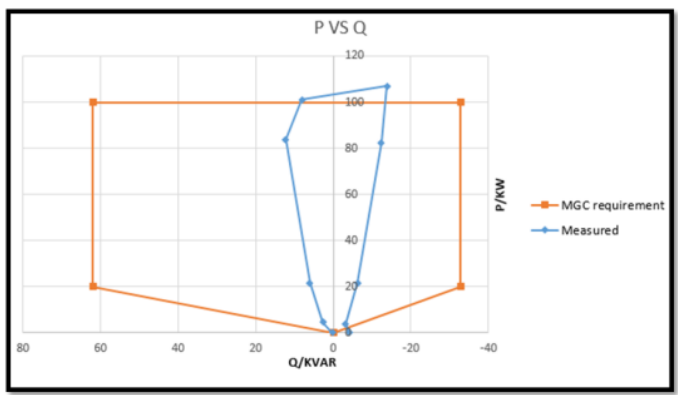

Figure $13 P \vee S Q$ for light load without capacitor bank

From the data in Table 5, graph $P$ VS $Q$ has been plotted in the same graph as the MGC requirement, as shown in Figure 13. As you can see from the figure, the inverter control is capable of supplying and absorbing reactive power but it not adequate to fulfil the Malaysian Grid Code requirement of 0.85 power factor lagging to 0.95 power factor leading.

\subsection{Peak load: P VS Q With 3kvar Capacitor Bank}

From Table 6, with different penetration of active power, $\mathrm{P}$ injected at the inverter and added of the capacitor bank, the system is able to absorb (lagging) and supply (leading) reactive power, $Q$ at PCC. The highest $Q$ it can absorb is $13.4 \mathrm{~kW}$, and highest $Q$ it can supply is -13.66 kvar.
Table 6 Data of Peak Load with a capacitor bank

\begin{tabular}{|c|l|l|l|}
\hline INVERTER (INJECTION) & \multicolumn{3}{|c|}{ PCC (MEASURE) } \\
\hline P/KW & \multicolumn{1}{|c|}{ P/KW } & Q/KVAR & V/PU \\
\hline \multicolumn{4}{|c|}{ Lagging/Overexcited } \\
\hline 0.1 & 0.3 & 0.3 & 0.14 \\
\hline 6.09 & 5.38 & 3.3 & 0.27 \\
\hline 24 & 22.02 & 5.76 & 0.5 \\
\hline 87.3 & 80.69 & 11.26 & 0.95 \\
\hline 117 & 109 & 13.4 & 1.1 \\
\hline \multicolumn{4}{|c|}{ Leading/Underexcited } \\
\hline P/KW & 98.66 & -13.66 & 1.05 \\
\hline 104 & 72.6 & -11.85 & 0.9 \\
\hline 76.66 & 18.71 & -6.12 & 0.44 \\
\hline 19.11 & 3.42 & -3.11 & 0.18 \\
\hline 3.16 & 0.06 & -4.14 & 0.12 \\
\hline 0.2 & & &
\end{tabular}

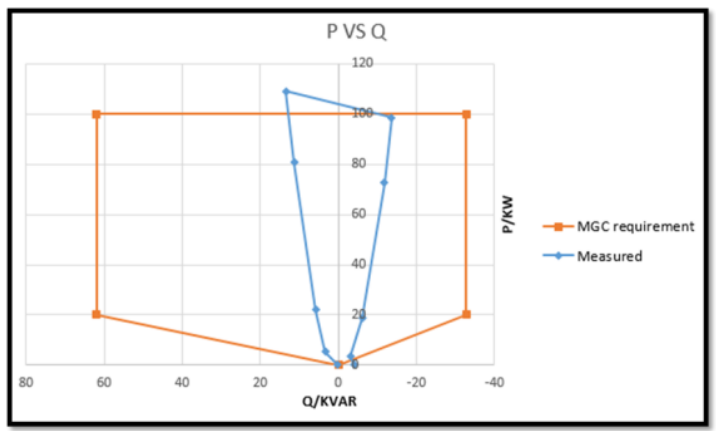

Figure $14 P$ VS $Q$ for peak load with capacitor bank

Table 6 showed the data when a capacitor added to the system. The graph P VS Q have been plotted in the same graph as the MGC requirement, as shown in Figure 14. As you can see from the figure, the inverter control is capable of supplying and absorbing reactive power. However, even when the capacitor bank is added to the system, it still not adequate to fulfil the Malaysian Grid Code requirement of 0.85 power factor lagging to 0.95 power factor leading.

\subsection{Light Load: P VS Q with 3kvar Capacitor Bank}

From Table 7, with different penetration of active power, $\mathrm{P}$ injected at the inverter and added of the capacitor bank, the system is able to absorb (lagging) and supply (leading) reactive power, $Q$ at PCC. The highest $Q$ it can absorb is $14.3 \mathrm{~kW}$, and highest $Q$ it can supply is -14.08 Kvar 
Table 7 Data of light load with a capacitor bank

\begin{tabular}{|c|c|c|c|}
\hline INVERTER (INJECTION) & \multicolumn{3}{|c|}{ PCC (MEASURE) } \\
\hline $\mathrm{P} / \mathrm{KW}$ & $\mathrm{P} / \mathrm{KW}$ & $\mathrm{Q} / \mathrm{KVAR}$ & $\mathrm{V} / \mathrm{PU}$ \\
\hline \multicolumn{4}{|c|}{ Lagging/Overexcited } \\
\hline 0.62 & 0.2 & 0.3 & 0.15 \\
\hline 4.56 & 4.49 & 2.37 & 0.25 \\
\hline 23.54 & 22.65 & 6.078 & 0.53 \\
\hline 86.98 & 84.27 & 12.11 & 1.01 \\
\hline 114 & 117 & 14.3 & 1.16 \\
\hline \multicolumn{4}{|c|}{ Leading/Underexcited } \\
\hline $\mathrm{P} / \mathrm{KW}$ & $\mathrm{P} / \mathrm{KW}$ & Q/KVAR & V/PU \\
\hline 107 & 107 & -14.08 & 1.1 \\
\hline 81 & 81.4 & -12.54 & 0.95 \\
\hline 20.5 & 21.25 & -6.5 & 0.47 \\
\hline 3.7 & 4.2 & -3.08 & 0.17 \\
\hline 0.19 & 0.1 & -4.08 & 0.12 \\
\hline
\end{tabular}

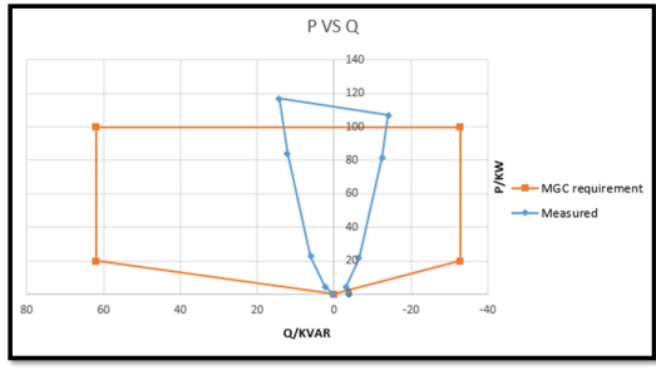

Figure $15 \mathrm{P} \vee S \mathrm{Q}$ for light load with a capacitor bank

The data in Table 7 are plotted into the graph $\mathrm{P}$ VS $Q$ as shown in Figure 15. From the figure, even when the capacitor bank has been added to the system, the inverter control still was not able to absorb and supply reactive power follow the MGC requirement but the result shows that it improved its capability at lagging side (positive side) compared to without capacitor bank in Figure 13.

\subsection{CONCLUSION}

In this study a grid-connected PV inverter controller that able to absorb and supply reactive power have been designed using Matlab/Simulink. Through this study, the capability of the inverter to absorb and supply reactive power follow the Malaysian grid code requirement (MGC) is being analysed, and the result shows that the inverter's controller not adequate to absorb and supply reactive power follow the MGC requirement. Last but not least, through this study, the PV solar system with reactive power compensator (capacitor bank) is analysed and compared with MGC requirement. The result shows that even with the capacitor bank, the controller still not capable of following the MGC requirement. For the future work, the further investigation and simulation will be carried out with other types of reactive power compensator such as STATCOM and SVC.

\section{Acknowledgement}

The authors would like to express the appreciation to Universiti Teknikal Malaysia, Melaka (UTeM) and Universiti Teknologi Malaysia (UTM) for the support of the sponsors [Vot Number $=$ Q.J130000.3551.07G53] .

\section{References}

[1] E. E. Pompodakis, I. A. Drougakis, and I. S. Lelis. 2015. Photovoltaic Systems in Low-voltage Networks and Overvoltage Correction with Reactive Power Control. IET Renewable Power Generation. 1-8. Available: 10.1049/ietrpg.2014.0282.

[2] First Photovoltaic Devices. 2015. PV Education.org. Accessed December 15, 2015. Available: http://www.pveducation.org/pvcdrom/manufacturing/firs t-photovoltaic-devices.

[3] L. Krishna. 2015. Optimal Design of Reactive Compensation Capability of a Solar Pv Plant.

[4] G. Your and F. Quote. 2019. History of Solar Energy: Who Invented Solar Panels? Who Invented Solar Panels? Solar Power Cell Technology Invented. 1-10.

[5] A. Cabrera-Tobar, E. Bullich-Massagué, M. AragüésPeñalba and O. Gomis-Bellmunt. 2016. Reactive Power Capability Analysis of a Photovoltaic Generator for Large Scale Power Plants. 5th IET International Conference on Renewable Power Generation (RPG) 2016, London. 1-6, Doi: 10.1049/cp.2016.0574.

[6] H. Karbouj, Z. H. Rather and B. C. Pal. 2020. Adaptive Voltage Control for Large Scale Solar PV Power Plant Considering Real Life Factors. IEEE Transactions on Sustainable Energy. Doi: 10.1109/TSTE.2020.3029102.

[7] A. Ellis et al. 2012. Reactive Power Performance Requirements for Wind and Solar Plants. IEEE Power Energy Soc. Gen. Meet. 1-8. Available: 10.1109/PESGM.2012.6345568.

[8] E. Demirok, P. C. González, K. H. B. Frederiksen, D. Sera, P. Rodriguez, and R. Teodorescu. 2011. Local Reactive Power Control Methods for Overvoltage Prevention of Distributed Solar Inverters in Low-voltage Grids. IEEE J. Photovoltaics. 1(2): 174-182. Available: 10.1109/JPHOTOV.2011.2174821.

[9] Nicholas Nixon Opiyo. 2018. Droop Control Methods for PV-Based Mini-Grids with Different Line Resistances and Impedances. Smart Grid and Renewable Energy. 9(6). Available: 10.4236/sgre.2018.9600.

[10] Wenlei Bain, M. Reza Abedi, Kwang Y. Lee. 2016. Distributed Generation System Control Strategies with PV and Fuel Cell in Microgrid Operation. Science Direct. February 52016.2 Available: https://doi.org/10.1016/j.conengprac.2016.02.002.

[11] Hassan Bevrani, Bruno François, Toshifumi Ise. 2017. Microgrid Dynamics and Control. John Wiley \& Sons.

[12] A. Cabrera-Tobar, M. Aragüés-Peñalba and O. GomisBellmunt. 2018. Effect of Variable Solar Irradiance on the Reactive Power Response of Photovoltaic Generators. 2018 IEEE International Conference on Environment and Electrical Engineering and 2018 IEEE Industrial and Commercial Power Systems Europe (EEEIC/I\&CPS), Palermo. 1-6. Doi: 10.1109/EEEIC.2018.8494417.

[13] A. Al-Shetwi and M. Sujod. 2018. Grid-connected Photovoltaic Power Plants: A Review of the Recent Integration Requirements in Modern Grid Codes. International Journal of Energy Research. 42(5): 1849-1865. Available: 10.1002/er.3983 [Accessed 17 May 2020]. 
[14] M. Hagh, S. Roozbehani and S. Ghasemzadeh. 2017. Dynamic Reverse Droop Power Sharing in Microgrid Based on Neural Networks. Procedia Computer Science. 120: 766-779. Available: 10.1016/j.procs.2017.11.307.

[15] W. Kou, D. Wei, P. Zhang and W. Xiao. 2015. A Direct Phase-coordinates Approach to Fault Ride Through of Unbalanced Faults in Large-scale Photovoltaic Power Systems. Electric Power Components and Systems. 43/810): 902-913. Available: 10.1080/15325008.2015.1014580 [Accessed 17 July 2020].

[16] A. Vinayagam, K. Swarna, S. Khoo, A. Oo and A. 2017. PV Based Microgrid with Grid-Support Grid-Forming Inverter Control-Simulation and Analysis. Smart Grid and Renewable Energy. 08(01): 1-30. Available: 10.4236/sgre.2017.81001 [Accessed 17 July 2020].

[17] W. Guo and L. Mu. 2016. Control Principles of MicroSource Inverters Used in Microgrid. Protection and Control of Modern Power Systems. 1(1). Available: 10.1186/s41601016-0019-8 [Accessed 17 July 2020].

[18] G. Adamidis, G. Tsengenes and K. Kelesidis. 2010. Three Phase Grid Connected Photovoltaic System with Active and Reactive Power Control Using Instantaneous Reactive Power Theory. Renewable Energy and Power Quality Journal. 1 (08): 1086-1091. Available: 10.24084/repqj08.591.

[19] H. Li, H. Zhang, F. Ma and W. Bao. 2014. Modeling, Control and Simulation of Grid-connected PV System with DSTATCOM. 2014 IEEE International Conference on System Science and Engineering (ICSSE). Available: 10.1109/icsse.2014.6887898 [Accessed 17 July 2020]

[20] A. Cabrera-Tobar, E. Bullich-Massagué, M. AragüésPeñalba and O. Gomis-Bellmunt. 2016. Reactive Power Capability Analysis of a Photovoltaic Generator for Large Scale Power Plants. 5th IET International Conference on Renewable Power Generation (RPG) 2016, London. 1-6. Doi: 10.1049/cp.2016.0574. 